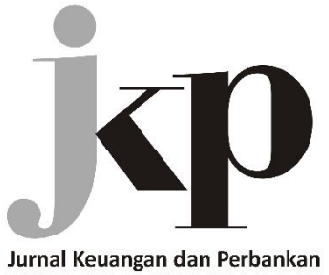
Jurnal Keuangan dan Perbankan
UN $V E K S Y$ Y U IVERDEKA MALANG

Article History:

Received: 2018-03-21

Revised: 2018-05-21

Accepted: 2018-07-08

Sigit Handoyo \& Safri Fathurrizki

Department of Accounting, Faculty of Economics, Islamic University of Indonesia Jl. Ringroad Utara, Condong Catur, Sleman, Yogyakarta, 55283, Indonesia
Sigit Handoyo(Indonesia), Safri Fathurrizki (Indonesia)

\section{Management Dysfunctional Behaviour toward Financial Statements: Income Smoothing Practice in Indonesia's Mining Industry Sector}

\begin{abstract}
Companies tried to maintain reported fluctuations in earnings and intervene them to the desired level. With the practice of income smoothing, the information was presented in financial statements; especially income statement became invalid so that it will mislead information to the users. We analyzed the factors influencing the income smoothing practice. Populations in this study were 45 mining companies listed on Indonesian Stock Exchange (IDX). The data used in this study was a secondary data screened by using purposive sampling method. Variables used in this research were company size measured by total assets, profitability proxied by return on assets, dividend payout ratio was proxy by comparing the dividend per share divided by earning per share, financial leverage was proxied by debt to total assets, and income smoothing was measured using Eckel index as dependent variable. This study used logistic regression tools. We found that dividend payout ratio and financial leverage gave significant positive effect to income smoothing practice. However, the size of the company and profitability did not affect to influence income smoothing practice. The investor who willing to invest in shares, it was important to scrutinize dividend payout ratio and financial leverage level of the future company.
\end{abstract}

Keywords: Company Size; Dividend Payout Ratio; Financial Leverage; Income Smoothing

\section{JEL Classification: L25, G35}

Citation: Handoyo, S., \& Fathurrizki, S. (2018). Management dysfunctional behaviour toward financial statements: income smoothing practice in Indonesia's mining industry sector. Jurnal Keuangan dan Perbankan, 22(3), 429-442. https:/ /doi.org/10.26905/jkdp.v22i3.1820

\section{Abstrak}

Perusahaan berusaha mempertahankan fluktuasi laba yang dilaporkan dan mengintervensi mereka ke tingkat yang diinginkan. Dengan praktik perataan laba, informasi yang disajikan dalam laporan keuangan, terutama laporan laba rugi menjadi tidak valid sehingga akan menyesatkan informasi kepada pengguna. Kami menganalisis faktor-faktor yang memen aruhi praktik perataan laba. Populasi dalam penelitian ini adalah 45 perusahaan pertambangan yang terdaftar di Bursa Efek Indonesia (BEI). Data yang digunakan dalam penelitian ini adalah data sekunder yang disaring dengan mengounakan metode purposive sampling. Variabel yang digunakan dalam penelitian ini adalah ukuran perusahaan diukur dengan total aset, profitabilitas diproksikan dengan return on assets, dividend payout ratio diproksikan dengan membandingkan dividen per share earning per share, financial leverage yang diproksikan dengan debt to total asset, dan perataan laba diukur dengan menggunakan indeks Eckel sebagai variabel dependen. Penelitian ini menggunakan alat regresi logistik. Kami menemukan bahwa rasio pembayaran dividen dan leverage keuangan memberikan pengaruh positif yang signifikan terhadap praktik perataan laba. Namun, ukuran perusahaan dan profitabilitas tidak berpengaruh untukmemengaruhi praktik perataan laba. Investor bersedia untuk berinvestasi dalam saham, penting untuk meneliti rasio pembayaran dividen dan tingkat leverage keuangan perusahaan di masa depan.

Kata Kunci: Ukuran Perusahaan, Rasio Pembayaran Dividen; Leverage Keuangan; Perataan Laba 


\section{Jurnal Keuangan dan Perbankan | FINANCE}

Volume 22, Issue 3, July 2018: 429-442

The financial statements are a description of the company's financial condition in a particular period that is intended to provide information to both internal and external parties. According to IASB (2008), the primary objective of financial reporting is to provide high-quality financial reporting information concerning economic entities, primarily financial, useful for economic decision making. Since the performance of the management can be indicated from the company's financial statements, the financial statements become a relevant means to account for what has been done by the management to the resources of the company under its management. Therefore, the financial statements should contain complete but concise information.

According to Indonesia Accountant Association (IAI) in The Statement of Financial Accounting Standards (IAI, 2017), a complete financial report consists of components of the balance sheet, income statement, statement of owner equity, cash flow statement, and notes to the financial statements.

However, users of financial statement information are more interested in the earnings information provided in the income statement because profit in the income statement is also an indicator in assessing management performance. Profitability is an important measurement to assess whether or not a company will affect investors in decision making. This causes management to tend to conduct undue behavior (dysfunctional behavior) by doing income smoothing practice in various ways (Hepwort, 1953). Similar statements were also raised by Tokuga \& Ayami (2011) who stated that companies generally prefer to report a stable profit growth trend and always try to control fluctuations in reported earnings rather than showing profoundly increasing or decreasing earnings changes.

Companies try to maintain reported fluctuations in earnings and intervene them to the desired level. Either managing reported figures to increase earnings when management thinks its initially planned term-end settlement targets (smoothing level figures) cannot be achieved or managing reported figures to decrease earnings or when the achievement of earnings higher than planned is certain may be implemented during a given fiscal period. This type of management behavior in accounting is called income smoothing behavior (Tokuga \& Ayami, 2011). Because of the difficulty detected by the users of financial statements, income smoothing practice has been considered as a means for management to manipulate accounting variables (Chong, 2006; Harnovinsah \& Indriani, 2015). According to Saeidi (2012), companies with low profitability level have a greater tendency to income smoothing practice and the higher the profitability of the company, the better the management performance in managing the company so that smaller possibility in income smoothing practice. With the practice of income smoothing, the information is presented in the financial statements, especially income statement is becoming invalid so it will mislead information to the users, especially external parties that result in the occurrence of a mistake in decision-making. An entity mostly does the practice of income smoothing because most investors only look from the information of the profits generated by the company (Chong, 2006). Investors are only oriented to the dividend (dividend payout ratio) which will be obtained which also depends on the size of the company's profits. Therefore, it was why management tries to 'fix' profits in order to reflect the increase in the value of the company by taking the income smoothing (Chong, 2006).

In Indonesia, the practice of income smoothing has long been noted, such as cases that occurred at PT Kimia Farma Tbk in 2001, it was found that there were overstated sales and inventory on several units within the company so that the net profit in the report was reported to be larger. In addition, in 2011 PT. Ancora Mining Service (AMS) was reported by Forum Masyarakat Peduli Keadilan (FMPK) to the Directorate General of Taxation (DJP) of the Ministry of Finance by alleged manipulation 
of financial statements. Chairman of the FMPK Investigation Section, Mustopo explained that the indication of manipulation was seen from the income of IDR 34.9 billion, but there was no movement of investment. It was also found evidence of interest payment of IDR 18 billion, although AMS admitted to not having debt. FMPK also found evidence that there was a receivable account worth IDR 5.3 billion but there was no clear transaction (Katarina, 2014).

There were still some findings on mining companies. Indonesia Corruption Watch (ICW) reported allegations of reporting manipulation of three sales of coal mining companies belonging to the Bakrie Group to the Directorate General of Taxation. ICW suspected the reporting engineered by PT Bumi Resources Tbk and a subsidiary causing a loss of $\$$ 620.49 million. ICW calculations using various primary data including audited financial statements showed that the sales report of Bumi during 20032008 was lower than $\$ 1.06$ billion from the actual value. As a result of that year, the country was estimated to suffer losses from the shortage of revenue from the Coal Production Fund (royalty) of \$ 143.18 million (Katarina, 2014).

Then based on Katarina's (2014), known Bakrie Group continued to experience losses due to the financial performance, where liquidity was at a minimal level. With the condition experienced by the Bakrie Group, according to Head of Research Securities Trust, Reza Priyambada, it was caused by the miss-management or less good management performance. The Bakrie Group issue was also reported in www.kabar24.com, where Rothschild is rumored to have resigned from the board of directors of Bumi Plc, a mining business group he founded with the Bakrie family who was judged to be cheating. So far it is rumored that Earth Plc. still has the possibility of misappropriation of more than \$ 500 million in the subsidiary in Indonesia.

Several studies on the practice of income smoothing that has been done in Indonesia show inconsistent results, such as Alexandri \& Anjani
(2014) study found that firm size, profitability, and financial leverage had a positive effect on income smoothing practices. In contrasts, the research done by Christiana (2012) by using sampling all companies manufacturing sector listed on the stock exchange Indonesia (IDX) between the years 20082010, found that firm size, profitability, financial leverage, and dividend payout ratio did not affect income smoothing practice.

In a research done by Rahmawati \& Muid (2012), it was found evidence that income smoothing is influenced by firm size. While the variable net profit margin and debt to equity ratio had no significant effect on the practice of equalization of profits made by the company. While in research done by Budiasih (2009) found evidence that firm size, profitability, and dividend payout ratio had a significant positive effect on the practice of income smoothing. Meanwhile, financial leverage had no significant effect on the practice of income smoothing.

Research by Veronica (2015), it was also found evidence that financial leverage did not affect the practice of income smoothing. While in their research, Indrawan et al. (2018), found evidence that the variable of financial leverage, profitability and audit committee had a significant negative effect on income smoothing, while firm size had a significant positive effect on the practice of income smoothing.

Theory of agency explained that there is asymmetry of information that a manager has more information about the company than the company owners or shareholders. Also stated by Jensen \& Meckling (1976), the agency theory implies the existence of information asymmetry between managers as an agent and shareholder as a principal. Information asymmetry is a situation in which managers have access to information on the prospect of a company that is not owned by an outsider (Agustia, 2013). Investors are only interested in profit in the form of financial returns from their investment in the company. Management will receive satisfaction 


\section{Jurnal Keuangan dan Perbankan | FINANCE}

Volume 22, Issue 3, July 2018: 429-442

not only in financial compensation but also from other additions involved in agency relationships, resulting in a tendency for managers to manipulate by income smoothing for personal gain.

On the other hand, according to Jensen \& Meckling (1976), there are two ways in identifying to reduce the chance managements do something action detrimental to investors, i.e., investors outside supervision (monitoring) and management make a limitation on actions (bonding). Both of these activities will reduce the opportunity of irregularities done by management so that the company's value will increase, while both will bring charges that will reduce the value of the company. Further, it was conducted by Jensen \& Meckling (1976) that a prospective investor would anticipate both these costs, coupled with losses that still occur even existing monitoring, and bonding that is called residual loss. The company will anticipate for the three charges which are defined as the cost of the agency (agency cost) by making a discount that will appear on the stock price when the company sells its shares.

Controls by investors are not easy to implement. Management has a policy in the field of finance to apply a standardized accounting policy but still have flexibility (Chong, 2006). That is why cases of manipulation accountant still occur and cannot be easily detected. This case was carried out to make the value of the company's shares which made earnings management stable and even increased. Earnings management according to Scott (1997) includes management efforts to maximize or minimize profits, including income smoothing in accordance with management's wishes. Earnings management is also the selection of accounting policies by managers of existing accounting standards and naturally can maximize their utility and/ or market value of the company. Scott (1997) divided the way understanding of earnings management into two. First, see it as an opportunistic behavior of managers to maximize its utility in the face of contracts of compensa- tion, debt contact, and political costs (Opportunistic Earnings Management). Secondly, by looking at earnings management from the perspective of efficient contracting (Efficient Earnings Management), where earnings management gives managers the flexibility to protect themselves and companies in anticipating unforeseen events for the benefit of the parties involved in the contract. Thus, managers can influence the market value of their company's stock through earnings management, for example by making income smoothing and profit growth over time.

The concept of earning management is closely related to the concept of income smoothing because income is a branch of earnings management issues even though the definition of income smoothing itself is still in a long debate. However, generally earning management is made by management with the aim of increasing the value of the company. Earnings management refers to the behavior that enterprise manager controls accounting earnings disclosed to the public without violation of accounting standards in order to maximize the interests of enterprise manager's own, instead of to improve corporate value. The purpose of earnings management is usually to smooth income, i.e., to keep the earnings of various periods relatively stable and avoid sharp fluctuation of enterprise income (Zhang, 2016).

Income smoothing is an intervention in the financial reporting process with the aim of showing multiple private gains (as opposed to the supposed: neutrality of the reporting process). Income smoothing occurs when managers use judgment in financial reporting and in the structure of transactions to alter financial statements. Judgment obscures some stakeholders regarding the performance of the economic conditions affecting the company or contractual outcomes that depend on accounting numbers reported (Kustono, 2009). These studies of income smoothing indicate that the flow of profits structure can influence the stability management posi- 


\section{Management Dysfunctional Behaviour toward Financial Statements:...}

Sigit Handoyo \& Safri Fathurrizki

tion of a company. This position determines the welfare and personal security of the manager. Thus, the management of a company is motivated to income smoothing practice as a method to improve welfare, both for shareholders and for management himself/herself.

The intentional smoothing which is most frequently performed by management (Chong, 2006). It can be said that intentional smoothing is concerned with situations where the reported profit is influenced by management actions that can be taken by management in response to changing economic conditions. It can also mean whether or not a real transaction can be done based on the effect of income smoothing. This alignment concerns the timing of real transaction events to achieve the target level. Management can also undertake a deliberate attempt to reduce artificial flow variability. This income smoothing is implemented by using accounting procedures to move costs and revenues from one period to another.

This research is aimed to analyze the factors influencing income smoothing practice. This research is a research development conducted by Alexandri \& Anjani (2014). In the previous study used dependent variables with indicators of company size, profitability, financial leverage. This study adds variable dividend payout ratio as referring to the research of Budiasih (2009), Noviana \& Yuyetta (2011), and Christiana (2012) because the four variables always gave inconsistent research result so that the researchers are interested in taking the variables. The background of why the mining company is selected as the research object because the performance of this industrial sector is extremely volatile from year to year influenced by world market prices.

\section{HYPOTHESES DEVELOPMENT}

In this study, the size of the company is proxies with Ln value of the total assets. The general definition of assets is all resources controlled by the company as a result of past events and is expected to provide economic benefits for the company in the future (IAI, 2017). It can be said that the total value of the asset is used on the basis that the total value of the assets reflects the property or property owned by the company. Rahmawati \& Muid (2012) argued that companies with large assets are usually called large corporations and would get more attention from various parties such as analysts, investors, and governments. Companies are also expected to avoid fluctuations in profits that are too drastic because a drastic increase in profits will cause increased taxes, and if the company experienced a drastic decline in profits it would result in the value of the company becomes less good so that managers tend to perform an income smoothing action practice.

Large-scale companies will tend to be more popular for the public so investors will easily access that information about the prospects of large-scale companies in the future than information about prospects of small-scale companies in the future. It has been evidenced recently by Herni \& Yulius (2008), Rahmawati \& Muid (2012), and Alexandri \& Anjani (2014) that larger firms have a drive to smoothing earnings compared to smaller firms because larger firms are studied and viewed more critically by investors. Also, bigger companies have a greater ability in performing creative accounting so that it tends to play accounting methods in earnings management because of the complexity of its operations (Ajibolade, 2008; Norri, 2013). Referring to the above description, the hypotheses that can be tested in this study are as follows:

$\mathrm{H}_{1}$ : company size has a positive effect on income smoothing practices

Profitability is an important indicator for measuring companies in generating profits. Therefore, the profitability of a company can be obtained by comparing the profit earned in a period with the number of assets or capital owned by the company. 


\section{Jurnal Keuangan dan Perbankan | FINANCE}

Volume 22, Issue 3, July 2018: 429-442

Profitability is an important measurement to assess whether or not the company affects investors to make decisions. Profitability is often used as a basis for dividend distribution with the assumption that investors do not like big risk and like stable profit. If within the company there is great profit variability, managers tend to make income smoothing in the hope that high profitability will raise the standard bonus or earnings in the future and reduce the manager's concerns in achieving the target of a stable profit in the future. Therefore, management tries to achieve a planned profit by applying accounting manipulation to earn earnings management (Tokuga \& Ayami, 2011).

Profitability can be measured by using return on assets (ROA). ROA is derived from net income after tax divided by total assets. Profit before income smoothing is obtained by reducing the net profit by the value of total accruals because by using these measures can be seen the company is healthy or not and will affect the decision of the investor. Firms with higher ROA tend to make earnings statements compared to lower firms because management knows the ability to earn future profits, making it easier to delay or accelerate earnings. The previous research conducted by Herni \& Yulius (2008) shows that profitability has a positive effect on the practice of income smoothing. Based on the above description, the hypotheses that can be tested in this study are as follows:

$\mathrm{H}_{2}$ : profitability has a positive effect on income smoothing practice

The concept of dividend payout ratio can be defined as the number of dividends paid to stockholders relative to the amount of total net income of a firm. This ratio indicates the percentage of net income paid out during the year in the form of cash dividend. It measures the percentage of a company's net income that is given to shareholders in the form of dividends. It means that the larger dividend pay- out ratio describes, the more profits generated by the company, as well as to the contrary (Ogilo, 2016).

Investors like companies that provide large dividends and greater dividend payments, managers would be more encouraging income smoothing practices and would try to maximize profits (Denis \& Osobov, 2008; Huang, You, \& Lin, 2009). However, Noviana \& Yuyetta (2011) argue that the dividend payout ratio is one factor that allegedly affects earnings smoothing action. In the case of fluctuations in earnings, firms implementing dividend policies with high dividend payout ratios are at greater risk than firms with low dividend payout ratio policies. Thus, a company that implements a high-level dividend payout ratio policy is more likely to take income smoothing action. Management wants to increase the value of the company (Tyastari, Rosidi, \& Saraswati, 2017).

Purwanto (2009) stated that the dividend payout ratio greatly influences the behavior of income smoothing. The dividend policy will have significant implications on the decision of the investor as well as the potential investment in the purchase of the company's shares. Based on the above description, the hypothesis that can be tested in this study are as follows:

$\mathrm{H}_{3}$ : dividend payout ratio has a positive influence on income smoothing practice

Financial leverage shows the proportion of debt used to finance its investment. The greater the debt of the company, the greater the risk will be faced by investors so that investors will ask for a higher level of leverage. It can be said that the use of higher debt could lower the positive effect of investment from the investors (Wijaya \& Wardani, 2017). Therefore, companies tend to perform income smoothing practices as a result of the condition.

Budiasih (2009) argued that the greater the company's debt, the greater the risks faced by investors so that investors will ask for higher profit 


\section{Management Dysfunctional Behaviour toward Financial Statements:...}

Sigit Handoyo \& Safri Fathurrizki

levels. The higher the financial leverage ratio represents, the more debt financed. This is an unhealthy condition and causes investors to be reluctant to invest because the higher the ratio of financial leverage, the higher the manager's encouragement to income smoothing practice.

Debt is one of the alternative funding policies of the company in addition to selling shares in the capital market. If the debt is used effectively and efficiently, it will increase the company's value. Companies that have high debt will then choose the accounting policy and shift future earnings into the present. According to Christiana (2012), the higher ratio of financial leverage describes the more expenditure -financed by debt. This is an unhealthy condition, and causing investors to be reluctant to invest because the higher the leverage ratio, the higher the manager's encouragement to practice income smoothing.

To measure financial leverage can be proxy with debt to total assets acquired through total debt divided by total assets. An indication that the company did the practice of income smoothing to avoid a breach of debt agreement can be seen from the company's ability to pay off its debts by using assets owned. Firms with high leverage rates are expected to practice income smoothing because the company is in danger of default so management makes policies that can increase revenue. Based on the above description, the hypothesis that can be tested in this study are as follows:

$\mathrm{H}_{4}$ : financial leverage has a positive influence on income smoothing practice

\section{METHODS}

The population of this research is mining companies listed on IDX (Indonesia Stock Exchange). The sample is taken by using purposive sampling method with the criteria of the company to be sampled: (1) mining companies that have been listed on the Indonesia Stock Exchange since 2012 which issued the financial statements as of December 31 for the period 2012-2014, and have complete financial statements in accordance with the data which is required in the research variables; (2) mining companies that have not suffered losses since 2012-2014; and (3) companies that present their financial statements in rupiah currency.

The type of data used in this study is secondary data from mining companies listed on the Indonesia Stock Exchange (IDX), which are the annual financial statements of going public mining companies. Data collection method used in this research is literature study and through documentation method. While the dependent variable in this study is the practice of income smoothing and independent variables in this research are company size, profitability, financial leverage, and dividend payout ratio.

The dependent variables were the focus of research is the practice of smoothing earnings. According to Budiasih (2009), income smoothing will be measured using the Eckel index. The Eckel index will differentiate between firms that practice income is smoothing with those who do not the practice of income smoothing. The following formula calculates the earnings smoothing index:

Index Eckel $=\frac{C V \Delta I}{\mathrm{CV} \Delta \mathrm{S}}$

Information:

$\mathrm{CV} \Delta \mathrm{I}$ : variation coefficient for earnings change

$\mathrm{CV} \Delta \mathrm{S}$ : coefficient of variation for sales changes

$\mathrm{CV} \Delta \mathrm{I}$ and $\mathrm{CV} \Delta \mathrm{S}$ can be calculated as follows:

$C V \Delta S$ or $C V \Delta I=\sqrt{\frac{\sum(\Delta x-\Delta \overline{\mathrm{x}})^{2}}{n-1}: \Delta \overline{\mathrm{x}}}$ 
Information:

$\Delta \mathrm{X}$ : changes in net income/profit (i) or sale (S) between year $n$ and $n-1$

$\Delta \mathrm{X}:$ average change in net income/profit (i) or sales (S) between year $n$ and $n-1$

n : years studied

The value of the income smoothing index $\geq 1$ means that the company is not classified as a company performing income smoothing. Conversely, if the income smoothing index $<1$, then the company is classified as a company doing income smoothing. The independent variable in this study consisted of:

Company size (CS) is measured by the natural logarithm of the total assets, the sample company during the five-year observation period. Natural logarithms can be formulated as follows:

Company size $=$ Ln Total Assets

Profitability (ROA), measured by the ratio between net income after tax and total assets (Budiasih, 2009):

Profitability $=$ Net Profit After-Tax $/$ Total Assets

Dividend payout ratio (DPR), measured by comparing dividend per share with earnings per share with the formula:

$D P R=($ Dividend per share $/$ Earning per share $) \times 100 \%$

Financial leverage (LEV), measured by the ratio between total debt and total asset. Financial leverage is proxied by debt to total assets by the formula:

Debt to Total Assets $=$ Total Debt $/$ Total Assets

Data processing using logistic regression analysis through SPSS software. The use of this model because the dependent variable is a dummy variable (income smoothing $=1$ and not income smoothing $=0$ ). Therefore, this analysis technique no longer needs a normality test and a classical assumption test on the independent variable (Ghozali, 2012). Since logistic regression ignores heteroscedasticity, meaning the dependent variable does not require homoscedasticity for each of its independent variables. The basis of decision making in the logistic regression analysis is to use the Hosmer and Lemeshow values Goodness of fit Test Statistic. If the results obtained significance equal to or less than 0.05 , then it means there is a significant difference between the models with the observation value (Ghozali, 2012).

Thus the analytical model can be expressed as follows:

$I S=a+b_{1} C S+b_{2} R O A+b_{3} D P R+b_{4} L E V$

Information:

IS : income smoothing

a : constants

CS : company size

ROA : profitability

DPR : dividend payout ratio

LEV : financial leverage

$b_{1,2,3,4}$ : regression coefficient of independent variables

\section{RESULTS}

\section{Descriptive Statistics Analysis}

From the results of descriptive analysis on Table 1, the minimum value of income smoothing amounts to 0 , which means that the company is not doing income smoothing while the maximum value of 1 means that the company did income smoothing. The average value of corporate income smoothing is 0.6486 or with a standard deviation of 0.48398 . The average value of income smoothing of 0.6486 can be interpreted that the number of companies that do income smoothing is equal to 64.86 percent. The standard deviation value of 0.48398 is 


\section{Management Dysfunctional Behaviour toward Financial Statements:...}

Sigit Handoyo \& Safri Fathurrizki

smaller than the average so it can be concluded that the income smoothing data is homogeneous.

Minimum value company size amount is 25.72 obtained by PT Mitra Investindo Tbk in 2012 which means that the company has the lowest size compared to other companies while the maximum value company size amount 32.05 obtained by PT Adaro Energy Tbk in 2013 which means that the company has the highest company size compared to other companies. Average value of the company for three years is as big as 29.7208 or with a standard deviation of 1.38544 . The average value of firm size amount is 29.7208 , and the value can be interpreted that the level of the company measured by total assets is 29.7208. The standard deviation of 1.38544 is smaller than the average, so it can be concluded that the firm's size data is homogeneous.

The minimum value of dividend payout ratio amount is 0.00002 obtained by PT Petrosea Tbk in 2014 which means that the company distributes the lowest dividend. While the maximum value of the dividend policy of 0.85 obtained by PT Indo Tambang Raya Megah Tbk in 2012 which means that the company has the highest dividend policy compared to other companies. Average value dividend policy year 2012-2014 is as big as 0.3578273 or with a standard deviation of 0.25784350 . Average value the largest dividend policy 0.3578273 and the value can be interpreted that the company's ability to pay a dividend is 0.3578273 . The standard deviation value of 0.25784350 is lower than the average so it can be concluded that the dividend policy data is homogeneous.
The minimum value of profitability amount is 0.0017 obtained by PT Vale Indonesia Tbk in 2014. It means that the company can generate the lowest profit compared to other companies while the maximum value profitability amount 0.3001 obtained by PT Harum Energy Tbk in 2012 means that the company can generate the highest profit compared to other companies. Average value profitability year 2012-2014 is as big as 0.088743 or with a standard deviation of 0.080689 . Average value profitability amount is 0.088743 , which can be interpreted that the company's ability level of the sample in generating profit is equal to 8.8743 percent. The standard deviation value of 0.080689 is smaller than the average so it can be concluded that the profitability data is homogeneous.

The minimum value of financial leverage amount is 0.18 obtained by PT Harum Energy Tbk in 2013, which means that the company has the lowest capital structure compared to other companies while the maximum value leverage amount is 0.80 obtained by PT RUIS Tbk in 2012, which means that the company has the highest capital structure compared to other companies. Average value leverage year 2012-2014 is as big as 0.4548 or with a standard deviation of 0.17304 . Average value leverage amount is 0.4548 , which can be interpreted that the level of ability to pay the debt of the assets amounted to 0.4548 . The standard deviation value of 0.17304 is smaller than the average so it can be concluded that the leverage data is homogeneous.

Table 1. Descriptive Statistics

\begin{tabular}{|c|c|c|c|c|c|}
\hline & $\mathbf{N}$ & Minimum & Maximum & Mean & Std. Deviation \\
\hline Income Smoothing & 37 & 0.0000 & 1.0000 & 0.6486 & 0.4839 \\
\hline Company Size & 37 & 25.7200 & 32.0500 & 29.7208 & 1.3854 \\
\hline ROA & 37 & 0.0017 & 0.3001 & 0.0887 & 0.0808 \\
\hline DPR & 37 & 0.0000 & 0.8465 & 0.3578 & 0.2578 \\
\hline LEV & 37 & 0.1800 & 0.8000 & 0.4548 & 0.1730 \\
\hline Valid N (listwise) & 37 & & & & \\
\hline
\end{tabular}


Table 2. Logistic Regression Coefficient Test and Hypothesis Testing

\begin{tabular}{lrl}
\hline & B & Sig \\
\hline CS & -0.423 & 0.357 \\
ROA & 15.714 & 0.121 \\
DPR & 13.008 & 0.012 \\
LEV & 19.162 & 0.014 \\
Constant & -666 & 0.958 \\
\hline
\end{tabular}

Wald statistical test of the results of logistic regression was performed to examine the effect of each independent variable on the dependent variable. Logistic regression coefficients can be determined using p-value (probability value), i.e., comparing values $\mathrm{p}$ with á. The decision making in this test is the level of significance $(\alpha)$ which is 5 percent.

The results of hypothesis testing can be elaborated as follows: (1) hypothesis testing-first. Testing of the first hypothesis is done by testing the significance of the regression coefficients of the firm size variable. The first hypothesis of this study suggests that firm size has a positive effect on income smoothing.

Based on Table 2, $\mathrm{n}$ significance value on the hypothesis of 0.357 with regression coefficient value -0.423 and at the level of significance $\alpha=5$ percent; then the regression coefficient is not significant because of the significance of $0.357>0.05$, which can be concluded that firm size has no significant effect on income smoothing; (2) hypothesis testing-second. Testing of the second hypothesis is done by testing the significance of the regression coefficient of the profitability variable. The second hypothesis of this study indicates that profitability has a positive effect on income smoothing. Based on Table 2, n significance value on the hypothesis of 0.121 with regression coefficient value 15.714 and at the level of significance $\alpha=5$ percent; then the regression coefficient is not significant because of the significance of $0.121>0.05$, which can be concluded that profitability has no significant effect on income smooth- ing; (3) hypothesis testing-third. Testing of the third hypothesis is done by testing the significance of the regression coefficients of the variables dividend payout ratio. The third hypothesis of this study suggests that the dividend payout ratio has a positive effect on income smoothing. Based on Table 2, significance value on the hypothesis of 0.012 with regression coefficient 13.008 and at the level of significance $\alpha=5$ percent; then the regression coefficient is significant because of the significance of 0.012 $<0.05$, which can be concluded that dividend payout ratio have a significant positive effect on the income smoothing so; and (4) hypothesis testingfourth. Testing of the fourth hypothesis is done through testing the significance of regression coefficients of the variables financial leverage. The fourth hypothesis of this study suggests that financial leverage have a positive effect on income smoothing. Based on Table 2, significance value on the hypothesis of 0.014 with regression coefficient 19.162 and at the level of significance $\alpha=5$ percent; then the regression coefficient is significant because of the significance of $0.014<0.05$, which can be concluded that financial leverage has a significant positive effect on income smoothing.

\section{DISCUSSION}

\section{The Effect of Firm Size on Income Smoothing}

The results of this study have shown that firm size has no significant effect on income smoothing. It means that the size of the company does not give a contribution to income smoothing. The contributions size of the firm on the probability of income smoothing is likely due to investors ignoring the assumption that large companies always have a large asset total. The insignificance of this variable means there is not enough evidence to say that increasingly big the size of the company in the previous year affected the higher income smoothing practices conducted by the company in the current year. That's because the larger the firm size will become the public spotlight, so they tend not to income smoothing practice. 
Furthermore, amount and nature deal on large companies as well potentially have a transaction increasingly complex so that the practice of income smoothing increasingly difficult to do. The results of this study are consistent with the findings of the research conducted by Christiana (2012), Yendrawati \& Nugroho (2012), and Sherlita \& Kurniawan (2013) that firm size had no significant effect on income smoothing. However, this study also shows some different findings with the results of research conducted by Ajibolade (2008), Norri (2013), and Alexandri \& Anjani (2014) that not all large corporations that have a strong base for accounting manipulation have a greater tendency to get earnings management.

\section{The Effect of Profitability on Income Smoothing}

The results of this study prove that profitability does not significantly affect income smoothing. Profitability has been a major concern for creditors and investors. This main concern encourages company managers to be able to decide whether or not to implement income smoothing for the survival of the company. When profitability is higher, companies tend not to make income smoothing because companies will increasingly become the public spotlight. Companies should not take big risk actions that can risk the company's credibility. Another possibility of bias is caused by stable economic conditions that result in stable operation of the company so that the profit also tends not to fluctuate so that companies do not need to make income smoothing. These results have been consistent with previous results research from Christiana (2012), Saeidi (2012), Nafea, Vakilifard, \& Fathollahi (2013), Sherlita \& Kurniawan (2013), and Ratnaningrum (2016) that profitability has no significant effect on income smoothing.

\section{The Effect of Dividend Payout Ratio on Income Smoothing}

The results of this study prove that the dividend policy has a significant positive effect on income smoothing means increasingly aggressive dividend policy will result in increasing management tendency to smoothing corporate earnings.

The size of the dividend depends on the size of the profits obtained, so the company tends to practice income smoothing. Dividend payout ratio is also one of the factors that allegedly affect the action of income smoothing Noviana \& Yuyetta (2011). If fluctuations occur in earnings, firms implement dividend policies at a rate dividend payout ratio. The higher risks are higher than those that apply the dividend payout ratio policy the low one. Thus, a company that implements the dividend payout ratio policy the higher is more likely to take income smoothing action. Dividend payout ratio very closely related to the practice of income smoothing because of direct contact with the decision to be taken by investors in the purchase of company shares seen from the dividend policy which is given by the company. Also, investors prefer the companies that provide dividends so that indirectly will further encourage managers to practice income smoothing. These results are consistent with previous studies conducted by Noviana \& Yuyetta (2011), and Moradzadehfard \& Babaie (2012) shows that the dividend payout ratio positively affects the practice of income smoothing.

\section{The Effect of Financial Leverage on Income Smoothing}

The results of this study prove that leverage has a significant positive effect on income smoothing that is the greater the leverage will be increasingly improving the possibility of a corporate earnings statement. 
Financial leverage describes the ability of a company to pay its liabilities. The leverage ratio is the ratio used to measure a company's ability to fulfill its liabilities. This ratio describes how many companies are financed by debt. The higher the leverage ratio, the greater the company's debt. This ratio indicates the amount of risk faced by investors, so companies with high leverage ratio will be less attractive to investors.

Then in line with positive accounting theory that is creditor would provide its money if the debtor can pay. Company managers who breach credit agreements tend to choose accounting methods that have a performance-enhancing effect to maintain their reputation on external parties so that creditors will believe in providing loans if the company can guarantee to make payments for its $\mathrm{fu}-$ ture. Management will tend to do income smoothing which is reflected in debt compared to its capital becomes lower resulting in trust from the debtor to grant the loan.

This is an unhealthy condition and causes investors to be reluctant to invest because of higher financial leverage ratios, the higher the likelihood of managers in income smoothing (Christiana, 2012). According to Prabayanti \& Yasa (2010), is an indication that the company is carrying out income smoothing to avoid breaching the debt agreement is known from the company's ability to repay its debt using assets owned. Referring to various explanations, that financial leverage has a great opportunity in encouraging managers to practice in- come smoothing. This research is also in accordance with previous research by Alexandri \& Anjani (2014) and Zarnegar \& Hamidian (2016).

\section{CONCLUSION AND SUGGESTIONS}

\section{Conclusion}

The practice of dysfunctional behavior is often done by management as a result of its efforts to maintain the stability of a company's performance. Although the income smoothing practice would be difficult to detect by the user of the financial statements, this action cannot be ratified, especially concerning reporting of intentionally presenting incorrect information. The results of this study prove that dividend payout ratio and financial leverage contribute to the income smoothing practice. This study implies that with dividend payments, management expects investors to disregard whether the company practices income smoothing or not. The quality of financial leverage can also function as a prediction of the existence or at least the possibility that the company did the income smoothing practice.

\section{Suggestions}

For further research can use or add other external factors outside the model such as the mechanism of corporate governance and the quality of external auditor as independent variables that can prevent dysfunctional management behavior.

\section{REFERENCES}

Agustia, D. (2013). Pengaruh faktor good corporate governance, free cash flow, dan leverage terhadap manajemen laba. Jurnal Akuntansi dan Keuangan, 15(1), 27-42. Retrieved from: http://jurnalakuntansi. petra.ac.id/index.php/aku/ article/view/18856
Ajibolade, S. O. (2008). A survey of the perception of ethical behaviorof future Nigerian accounting professionals. Nigerian Accountants, 41(3), 54-59. Retrieved from: http:/ /ir.unilag.edu.ng: $8080 / \mathrm{xmlui} / \mathrm{h}$ andle / $123456789 / 2690$
Alexandri, M. B., \& Anjani, W. K. (2014). Income smoothing: Impact factor, evidence in Indonesia. International Journal of Small Business and Entrepreneurship Research, 3(1), 21-27. Retrieved from: http://www. eajournals.org/wp-content/ 
uploads/Income-SmoothingImpact-Factors-Evidence-InIndonesia1.pdf

Budiasih, I. G. A. N. (2009). Faktorfaktor yang mempengaruhi praktik perataan laba. Jurnal Imiah Akuntansi dan Bisnis, 4(1), 1-14. Retrieved from: https:// ojs.unud.ac.id/index.php/ jiab/article/view/2589

Chong, H. G. (2006). Is income smoothing ethical? Journal of Corporate Accounting and Finance, 18(1), 41-44. Retrieved from: https:/ / doi.org/10.1002/jcaf.20261

Christiana, L. (2012). Faktor-faktor yang mempengaruhi praktek perataan laba pada perusahaan manufaktur di BEI. Jurnal Ilmiah Mahasiswa Akuntansi, 1(4), 71-75. Retrieved from: http://download.portalgaruda. org / article.php? article $=$ $113975 \& \mathrm{val}=5211$

Denis, D. J., \& Osobov, I. (2008). Why do firms pay dividends? International evidence on the determinants of dividend policy. Journal of Financial Economics, 89(1), 62-82. Retrieved from: https://doi.org/10.1016/ j.jfineco.2007.06.006

Ghozali, I. (2012). Aplikasi Analisis Multivariate dengan Program SPSS.Semarang: Badan Penerbit Universitas Diponegoro.

Harnovinsah, \& Indriani, P. (2015). The market reaction and income smoothing (case study on listed company in LQ 45 Indonesian Stock Exchange). Research Journal of Finance and Accounting, 6(8), 104-112. Retrieved from: https://iiste.org/ Journals/index.php/RJFA/ article/view/21979

Hepworth, S. (1953). Smoothing periodic income. The Accounting
Review, 28(1), 32-39. Retrieved from: http://www.jstor.org/ stable/241436

Herni, \& Yulius K. S. (2008). Pengaruh struktur kepemilikan publik, praktik pengelolaan perusahaan, jenis industri, ukuran perusahaan, profitabilitas, dan risiko keuangan terhadap tindakan perataan laba (studi empiris pada industri yang listing di Bursa Efek Jakarta). Jurnal Ekonomi dan Bisnis Indonesia, 23(3), 302-314. Retrieved from: https://jurnal.ugm.ac.id/jieb/ article/view/6341

Huang, C. S., You, C. F., \& Lin, S. H. (2009). Cash dividends, stock dividends, and subsequent earnings growth. Pacific Basin Finance Journal, 17(5), 596-610. https://doi.org/10.1016/ j.pacfin.2009.03.002

IAI. (2017). Standar Akuntansi. Jakarta: Salemba Empat.

IASB (2008). Exposure draft on an improved conceptual framework for financial reporting: The objective of financial reporting and qualitative characteristics of decision-useful. Financial Reporting Information. London.

Indrawan, V., Agoes, S., Pangaribuan, H., \& Popoola, O. M. J. (2018). The impact of audit committee, firm size, profitability, and leverage on income smoothing. Indian-Pacific Journal of Accounting and Finance (IPJAF), 2(1), 6174. Retrieved from: http:// ipjaf.omjpalpha.com / index.php/ipjaf/article/ view $/ 42 / 34$

Jensen, M. C., \& Meckling, W. H. (1976). Theory of the firm: Managerial behavior, agency costs, and ownership structure.
Journal of Financial Economics, 3(4), 305-360. Retrieved from: https://doi.org/10.1016/ 0304-405X(76)90026-X

Kustono, A. S. (2009). Pengaruh ukuran, devidend payout, risiko spesifik, dan pertumbuhan perusahaan terhadap praktik perataan laba pada perusahaan manufaktur: Studi empiris Bursa Efek Jakarta 2002-2006. Jurnal Ekonomi Bisnis, 14(3), 200-205. Retrieved from: http://fe.um.ac.id/ wpcontent/uploads/2010/01/ alwan-sri-kustono_3.pdf

Moradzadehfard, M., \& Babaie, S. (2012). The impact of dividend policy on a firm's real earnings management: An empirical investigation in the Tehran Stock Exchange-listed companies. Research Journal of Business Management, 6(4), 144152. Retrieved from: https:// doi.org/10.3923/rjbm.2012. 144.152

Nafea, S., Vakilifard, H., \& Fathollahi, J. (2013). A survey of the relationship between income smoothing and stock market prices and financial ratios in accepted firms in Tehran Stock Exchange. Journal of Life Science and Biomedicine, 3(2), 135-139.

Noviana, S. R., \& Yuyetta, E. N. A. (2011). Analisis faktor-faktor yang mempengaruhi praktik perataan laba (Studi empiris perusahaan manufaktur yang terdaftar di BEI periode 20062010). Jurnal Akuntansi dan Auditing, 8(1), 69-82. Retrieved from: https:/ / ejournal.undip. ac.id/index.php/akuditi/article/view/4348

Ogilo, F. (2016). Determinants of dividends pay-out ratio for listed commercial banks in Kenya. 
The International Journal of Business $\mathcal{E}$ Management, 4(8), 46-51. Retrieved from: http:// www.theijbm.com/wp-content/uploads/2016/08/8.BM1608-002.pdf

Prabayanti, N. L. P. A., \& Yasa, G. W. (2010). Perataan laba (income smoothing) dan analisis faktorfaktor yang mempengaruhinya (Studi pada perusahaan manufaktur yang terdaftar di Bursa Efek Indonesia). Jurnal Universitas Udayana, 6(1), 1-28. Retrieved from: https://ojs. unud.ac.id/index.php/jiab/ article/view/2645

Purwanto, A. (2009). Karakteristik perusahaan, praktik corporate governance, keputusan keuangan, perataan laba, dan nilai perusahaan. Jurnal Maksi, 9(2), 175-189. Retrieved from: http://eprints.undip.ac.id/ 35093 / 1 / JMAKSI_Agt 2009_04_Agus_Purwanto.pdf

Rahmawati, D., \& Muid, D. (2012). Analisis faktor-faktor yang berpengaruh terhadap pratik perataan labba (Studi kasus pada perusahaan manufaktur yang terdaftar di BEI tahun 2007-2010). Jurnal Akuntansi Universitas Diponegoro, 1(2), 114. Retrieved from: https:// ejournal3.undip.ac.id/ index.php/accounting/article/view/374

Ratnaningrum. (2016). The influence of profitability and income tax on income smoothing rankings. Jurnal Bisnis dan Manajemen, 17(2), 133-143. Retrieved from: http://journal.feb.unpad.ac.id/ index.php/jbm/article/view/ 27
Saeidi, P. (2012). The relationship between income smoothing and income tax and profitability ratios in Iran Stock Market. Asian Journal of Finance $\mathcal{E}$ Accounting, 4(1), 46-51. Retrieved from: https://doi.org/ 10.5296/ajfa.v4i1.790

Scott, W. R. (1997). Financial Accounting Theory. $2^{\text {nd }}$ Edition. Canada: Prentices Hall.

Sherlita, E., \& Kurniawan, P. (2013). Analysis of factors affecting income smoothing among listed companies in Indonesia. Jurnal Teknologi, 64(3), 17-23. Retrieved from: https://sainshumanika. u t m.m y / index.ph p / sainshumanika/ article/view/62

Tokuga, Y., \& Ayami, S. (2011). Income smoothing as a form of accounting policy by income smoothing as a form of accounting policy by managersA case study of onward Kashiyama. Working Paper. Graduate School of Economics Kyoto University. Retrieved from: http://www.econ.kyotou.ac.jp/ chousa/WP/122.pdf

Tyastari, T. T. D., Rosidi, \& Saraswati, E. (2017). Dividend policy and corporate value (A meta-analysis). Jurnal Keuangan dan Perbankan, 21(3), 344-355. Retrieved from: http://jurnal. unmer.ac.id/index.php/jkdp/ article/view/1218

Veronica, A. (2015). The influence of leverage and its size on the earnings management. $\mathrm{Re}$ search Journal of Finance and Accounting, 6(8), 159-168. Retrieved from: https://iiste.org/ Journals/index.php/RJFA/ article/viewFile/21985/22425
Wardhani, K. R. (2014). Pengaruh profitabilitas, leverage, dan ukuran perusahaan terhadap manajemen laba (Studi pada perusahaan pertambangan yang terdaftar di Bursa Efek Indonesia pada tahun 20102012). Essay. Universitas Widyatama. Retrieved from: http://repository.widyatama. ac.id / x mlui / handle / 123456789/3704

Wijaya, H., \& Wardani, P. Rr. (2017). Debt and agency conflict in Indonesian manufacturing firms. Jurnal Keuangan dan Perbankan, 21(2), 200-210. Retrieved from: http://jurnal.unmer.ac.id/ index.php/jkdp/article/ view/659

Yendrawati, R., \& Nugroho, W. A. S. (2012). Struktur kepemilikan, ukuran perusahaan, dan praktek corporate governance terhadap manajemen laba. Jurnal Keuangan dan Perbankan, 16(2), 188-195. Retrieved from: http://jurnal. unmer.ac.id/index.php/jkdp/ article/view/1059

Zhang, X. G. (2016). Income smoothing, idiosyncratic risk, \& CEO turnover. Journal of Mathematical Finance, 6(1), 1-13. Retrieved from: https://doi.org/10.4236/ jmf.2016.61001

Zarnegar, Z., \& Hamidian, M. (2016). Examining the relationship between profitability, financial leverage and income smoothing at firms listed on Tehran Stock Exchange. Iranian of Journal Business and Economics, 3(3), 80-83. Retrieved from: http:// www.scijour.com/page/ download-ZAWRoWJSg14.artdl 